\title{
Lake Sam Rayburn Archaeological Site Inventory and Monitoring Project
}

Velicia Hubbard

Unknown

Follow this and additional works at: https://scholarworks.sfasu.edu/ita

Part of the American Material Culture Commons, Archaeological Anthropology Commons, Environmental Studies Commons, Other American Studies Commons, Other Arts and Humanities Commons, Other History of Art, Architecture, and Archaeology Commons, and the United States History Commons

Tell us how this article helped you.

This Article is brought to you for free and open access by the Center for Regional Heritage Research at SFA ScholarWorks. It has been accepted for inclusion in Index of Texas Archaeology: Open Access Gray Literature from the Lone Star State by an authorized editor of SFA ScholarWorks. For more information, please contact cdsscholarworks@sfasu.edu. 


\section{Lake Sam Rayburn Archaeological Site Inventory and Monitoring Project \\ Creative Commons License \\ (c) (1) \& 8}

This work is licensed under a Creative Commons Attribution-NonCommercial 4.0 International License 


\section{LAKE SAM RAYBURN ARCHAEOLOGICAL SITE INVENTORY AND MONITORING PROJECT}

\section{Velicia Hubbard}

In January 1995, the East Texas Archeological Society (ETAS), the U.S. Army Corps of Engineers (COE), the U.S. Forest Service (USFS), and the Texas Historical Commission (THC) agreed to cooperate in a partnership project to inventory and monitor archaeological sites along the Lake Sam Rayburn shoreline. A Letter of Intent (LOI-095-02) was formulated and signed, stating that:

the participants are mutually interested in fostering integrated problem solving among heritage resource managers regarding historic preservation issues, with special emphasis on training and information sharing. The Forest Service [and the COE] will gain additional information on the condition and location of archeological sites within its ownership along the shores of Sam Rayburn Reservoir. The participants will gain experience in recording and monitoring of site conditions, gain knowledge concerning the effects of shoreline erosion and looting of sites along the shores of Sam Rayburn Reservoir. Finally, the USFS and the COE will profit from the volunteer labor provided by members of ETAS.

This paper reports on inventory and monitoring project activities that took place on September 30, 1995, and October 7, 1995 along the northern end of Lake Sam Rayburn (Figure 1). Elaine P. Sherman was the Project Archeologist, and the work was conducted under ARPA permit no. DACW63-95-0656.

\section{Project Area}

The two project areas are at the northern end of the lake, one on a peninsula landform at the confluence of the Angelina River and Attoyac Bayou, and the other on the upper Attoyac Bayou arm of the lake (see Figure 1). Both project areas are fluviatile terraces of Pleistocene age; before the inundation of the lake, they were nearly level to gently sloping terraces with alternating mounds and low places. The survey area at the confluence of Attoyac Bayou and the Angelina River is now an island most of the year, with sparse hardwoods and sweetgum, and grasses growing on the higher part of the landform. 'The upper Attoyac Bayou area is located within the Townsend Recreation area on the east side of the Attoyac Bayou. Vegetation along the shoreline is very sparse, but pines and various grasses are present on higher lands to the east of the lake.

\section{NA 196}

To begin work at this site in the Angelina River-Attoyac Bayou confluence area, accessible only by boat, a Sunto compass and metric tape were used to establish an E100 baseline, and portions of seven $20 \times 20 \mathrm{~m}$ collection units were laid out (the southwest corner was used as the collection unit coordinate) (Figure 2). On the shoreline, the soil has been eroded, leaving clay exposed at the surface. The controlled surface collection area abuts a slightly higher and thickly wooded elevation. The site is inundated most times of the year. Site 41 NA 196 is about $125 \mathrm{~m}$ north-south and 50 m east-west in size. 


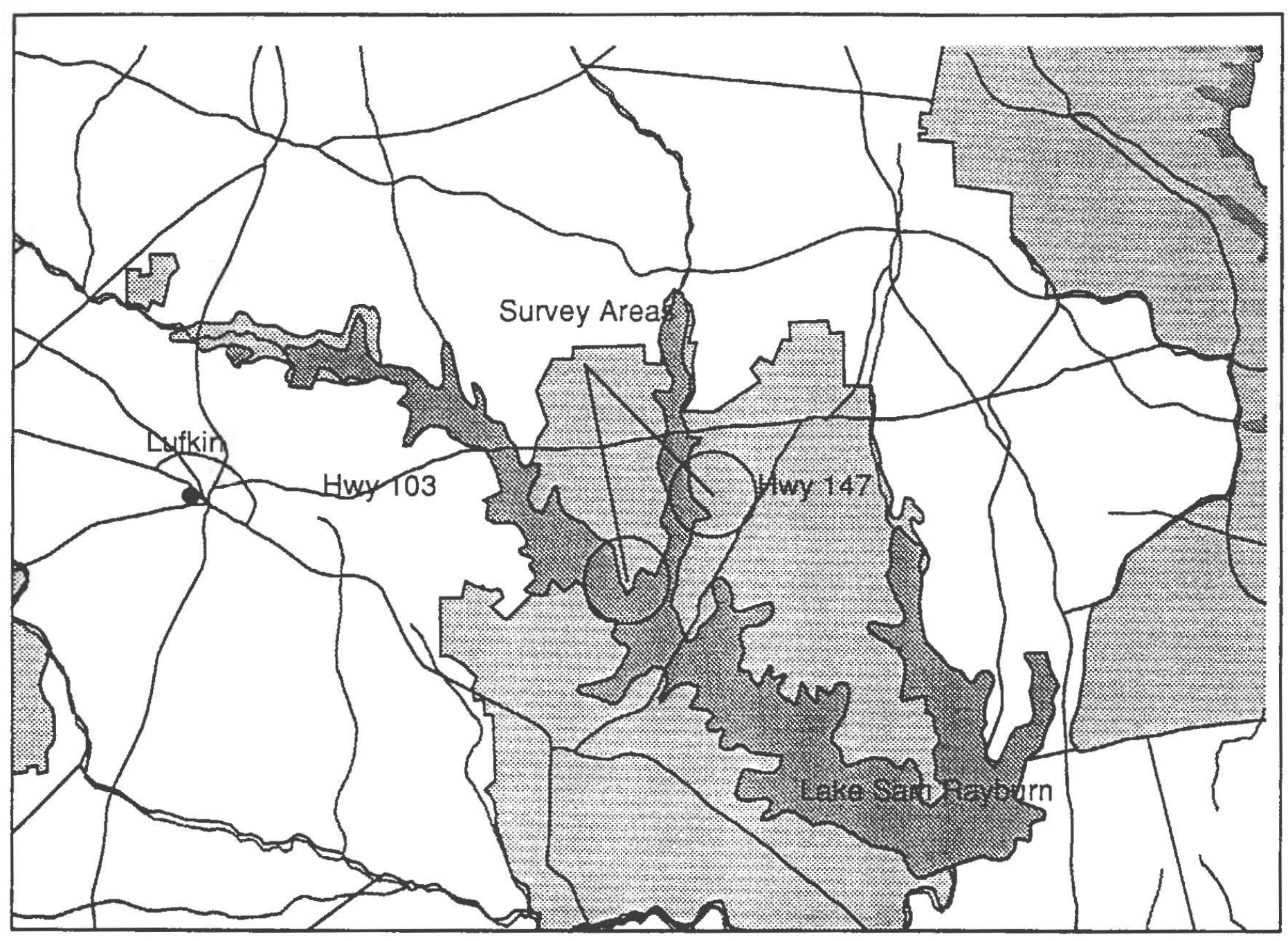

Figure 1. Survey Areas at Lake Sam Rayburn.

Each collection unit at 41NA196 was eroded to the point where the red clay B-horizon was exposed in most instances; there were noticeable amounts of slope-washed sand. A total of 1,004 artifacts collected from the site, mainly lithics, with five pottery sherds also present (Table 1). One of the five sandy paste sherds is a rim. A possible rock hearth or concentration of burned rocks was exposed in the southwest comer of N120E100 (see Figure 2).

A total of 584 flakes and 26 cores of petrified wood were collected, and all but one of the eight projectile points and point fragments were of petrified wood. Two of the points were identified as the Ellis type; one was made of a local red chert. The three bifaces and one of the two preforms from the site were also made of petrified wood (Table 2). Other tools include scrapers, a hammerstone, and a knife.

Chert flakes totaled 260 , along with seven cores. Flakes of quartzite were also noted at the site. There were 17 milling stones of ferruginous sandstone recovered from across the collection areas. 


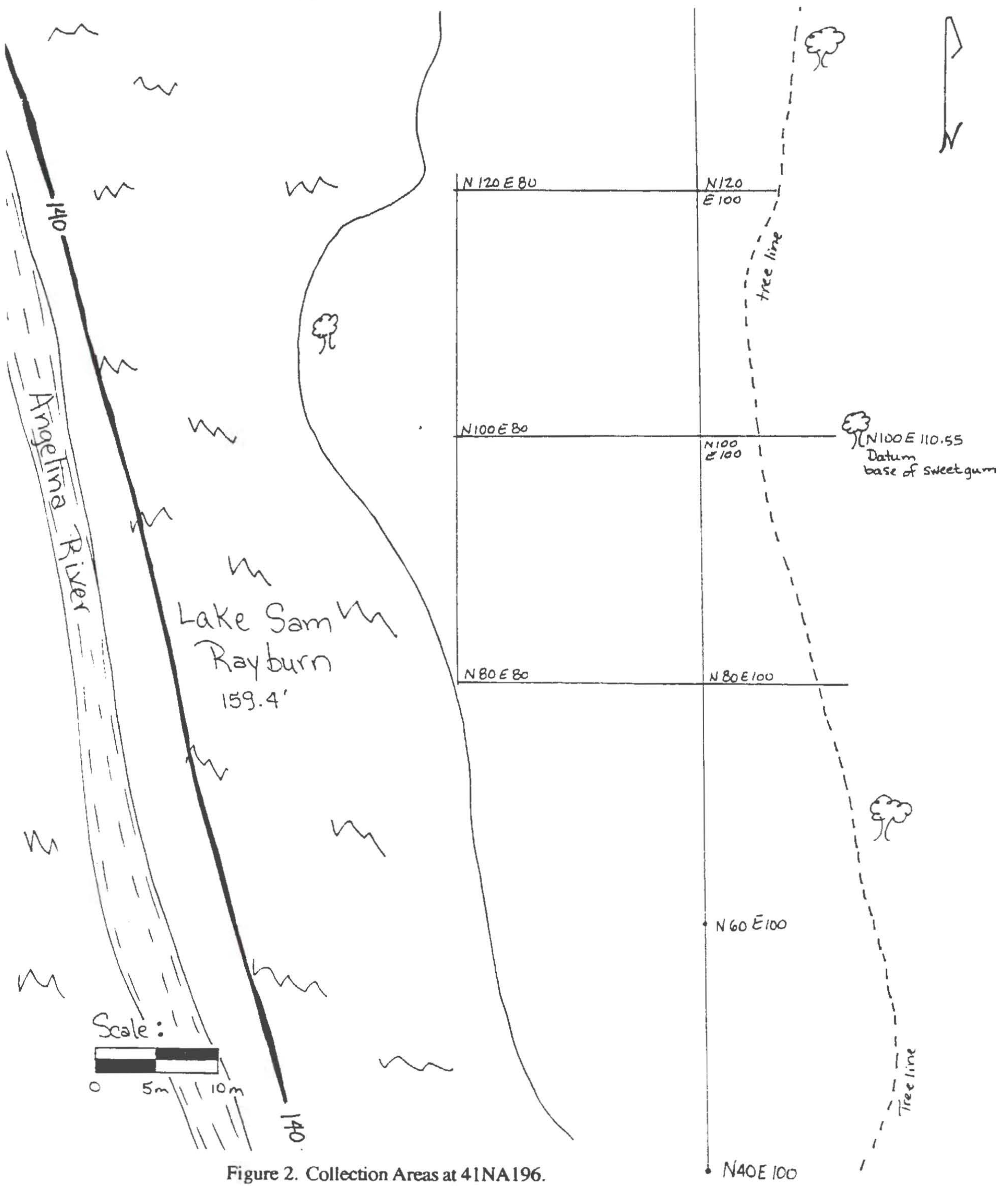


Table 1. 41NA196 Artifact Inventory

\begin{tabular}{|c|c|c|c|c|c|c|c|c|c|c|c|}
\hline Unit & $\mathrm{CF}^{*}$ & PWF & PWC, & $\alpha$ & Toxis & Points & Preforms & $\begin{array}{l}\text { Milling } \\
\text { Stones }\end{array}$ & Pottery & $\mathrm{QH}$ & Biface \\
\hline $\begin{array}{l}\text { S of } \\
\text { grid }\end{array}$ & 12 & 35 & - & & 15 & 5 & 2 & 2 & 2 & 3 & \\
\hline $\begin{array}{l}\text { gnd } \\
\text { N80/E80 } \\
\text { N100\% }\end{array}$ & $\begin{array}{l}12 \\
36\end{array}$ & $\begin{array}{l}35 \\
115\end{array}$ & $\overline{5}$ & 7 & 4 & $\begin{array}{l}3 \\
1\end{array}$ & $\begin{array}{l}2 \\
-\end{array}$ & 2 & 3 & - & 1 \\
\hline $\begin{array}{l}\text { F80 } \\
\text { N120/ }\end{array}$ & 100 & - & 10 & - & 13 & - & - & 6 & - & 38 & \\
\hline $\begin{array}{l}\mathrm{E} 80 \\
\text { N140 }\end{array}$ & 7 & 101 & 3 & - & 2 & 1 & - & 3 & - & 6 & - \\
\hline $\begin{array}{l}\mathrm{F80} \\
\mathrm{N} 80 /\end{array}$ & 10 & 77 & - & & 7 & - & - & 1 & - & - & 2 \\
\hline $\begin{array}{l}\text { E100 } \\
\text { N100 }\end{array}$ & 17 & 13 & 2 & - & - & - & - & 1 & & & - \\
\hline $\begin{array}{l}\text { E100 } \\
\text { N120 }\end{array}$ & 43 & 157 & 2 & - & 1 & 1 & - & - & - & - & - \\
\hline F100 & 35 & 86 & 4 & - & 3 & - & - & 2 & - & & \\
\hline Totals & 260 & 584 & 26 & 7 & 45 & 8 & 2 & 17 & 5 & 47 & 3 \\
\hline
\end{tabular}

* (H=chert flakes; PWF=petrified wood flakes; PWC=petrified wood cores; $(C=$ =chert cores; $Q F=$ =quartive flakes

Table 2. 41NA196 Tools

\begin{tabular}{lllll}
\hline Tool Type & Petrified Wood & Chert & Sandstone & Quartzite \\
\hline Scrapers & 29 & 14 & 1 & 1 \\
Projectile Points & 7 & 1 & - & - \\
Biface & 3 & - & - & - \\
Preform & 1 & 1 & - & - \\
Knife & 1 & - & - & - \\
Hammerstone & - & 1 & - & - \\
Milling Stones & - & - & 17 & 1 \\
\hline Totals & 41 & 17 & 18 & 1 \\
\hline
\end{tabular}

Site 4 INA196 will be monitored when lake levels drop from normal elevations, exposing the beach on the site. This activity will be coordinated by the $\mathrm{COE}$, and primarily carried out by ETAS volunteers.

\section{SA 191}

This site is in the Townsend Recreation area along Attoyac Bayou. Work consisted initially of walking the area and pin-flagging locations where artifacts were noted, then laying out an E120 base line. Due to the shoreline erosion and vegetation, the base line was moved 1 $\mathrm{m}$ to the west between N120 and N140. Seven $20 \times 20 \mathrm{~m}$ collection units were established, again with grid coordinates based on the southwest corner of the units (Figure 3 ). The lake abuts the western portion of the site, with the tree line to the east on a high knoll or toe 


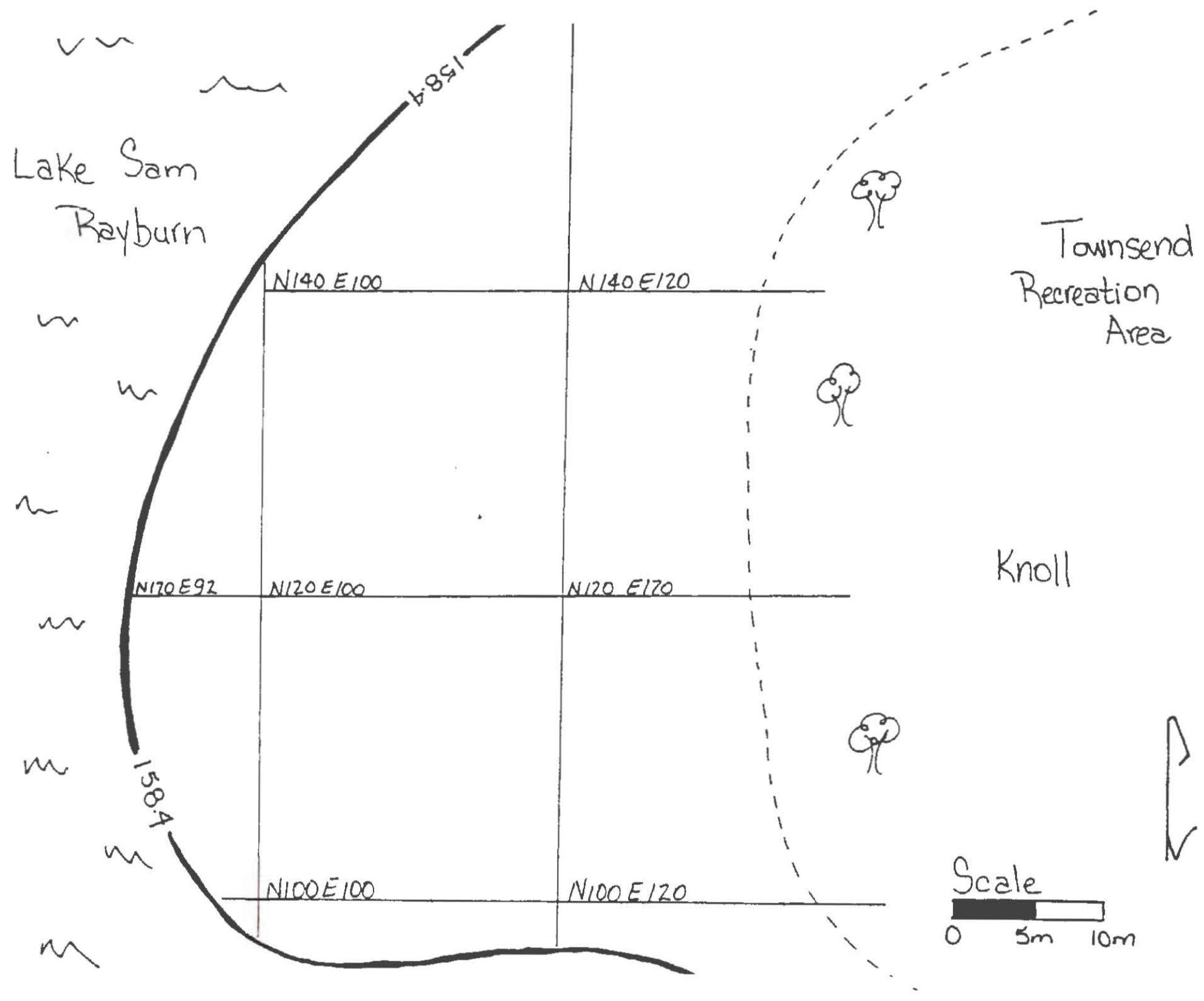

Figure 3. Collection Areas at 41SA191.

slope. On the shoreline, the soil is eroded, leaving clay exposed at the surface. Intact archaeological deposits are suspected to be preserved on the knoll.

Each of the collection units has been eroded, with red clay exposed in some areas; slopewashed sandy areas were also noticeable. A total of 73 artifacts were recovered from the collection units at 4ISA191 (Table 3). Petrified wood flakes and cores were common, and both projectile points were made of this raw material. Tools include scrapers, a possible knife, and hammerstone fragments. In addition, a possible Waco sinker of hematitic sandstone was recovered from the site; it measures $57 \mathrm{~mm}$ in diameter, and appears to have a pecked-out groove around the center. 
Table 3. 41SA191 Artifact Inventory

\begin{tabular}{|c|c|c|c|c|c|c|c|c|}
\hline Unit & Tools & $\begin{array}{l}\text { Chert } \\
\text { Cores }\end{array}$ & $\begin{array}{l}\text { Chert } \\
\text { Flakes }\end{array}$ & $\begin{array}{l}\text { Petrificd } \\
\text { Wood } \\
\text { Hlakes }\end{array}$ & Pottery & $\begin{array}{l}\text { Catahoula } \\
\text { Flake }\end{array}$ & Point Base & $\begin{array}{l}\text { Petrified Wood } \\
\text { Core }\end{array}$ \\
\hline $\begin{array}{l}\text { N. of } \\
\text { grid }\end{array}$ & 1 & 1 & 3 & 10 & 3 & - & & 2 \\
\hline $\begin{array}{l}N 100 / \\
\text { E.92 } \\
N 100 \%\end{array}$ & 2 & 1 & 1 & & & 1 & - & 2 \\
\hline $\begin{array}{l}\mathrm{H} 100 \\
\mathrm{~N} 100\end{array}$ & 1 & - & 3 & 4 & 7 & - & & - \\
\hline E120 & - & - & 1 & - & 1 & - & - & 1 \\
\hline $\begin{array}{l}N 1201 \\
\text { Filoo }\end{array}$ & - & 1 & & 11 & 7 & - & 1 & 1 \\
\hline $\begin{array}{l}N 120 \% \\
\text { E120 } \\
N 140 \%\end{array}$ & 1 & - & - & 1 & - & - & 1 & - \\
\hline Eino & - & - & 1 & 2 & - & - & & 1 \\
\hline Totals & 5 & 3 & 9 & 28 & 18 & I & 2 & 7 \\
\hline
\end{tabular}

Of the 18 sandy paste sherds from the site, four are rim sherds. None of the sherds are decorated.

Further work is recommended at 41SA191, including test excavations in the area of intact deposits within the treeline. Monitoring of this site and 41SA192 is necessary because this area is frequently visited by recreational collectors. The testing, and monitoring activities will be carried out by USFS personnel with the assistance of ETAS volunteers.

\section{SA192}

This site is just north of 41SA19l. It is a small locality (lithic materials are scattered over a $75 \mathrm{~m}$ stretch of the beach), with a seep spring running through it. General surface collections were completed here, with no baseline being established.

The beach area at the site is eroded, with numerous small gullies created by the seep. A small lake inlet separates 4ISA 192 from 41SA191, with the southernmost part of 41SA192 $90 \mathrm{~m}$ north of the northern limits of 41SA191 (Figure 4).

Artifacts were collected from the erosional gullies, with 38 artifacts found, including 26 petrified wood flakes. Also found were three petrified wood scrapers, two petrified wood cores, two chert cores, three chert flakes, and two sherds of sandy paste pottery.

Further work is recommended at 4ISA192, including site mapping and test excavations in the area of intact deposits within the treeline. Monitoring of this site and 41SA191 is also necessary because this area is frequently visited by recreational collectors. The mapping, testing, and monitoring activities will be carried out by USFS personnel with the assistance of ETAS volunteers. 


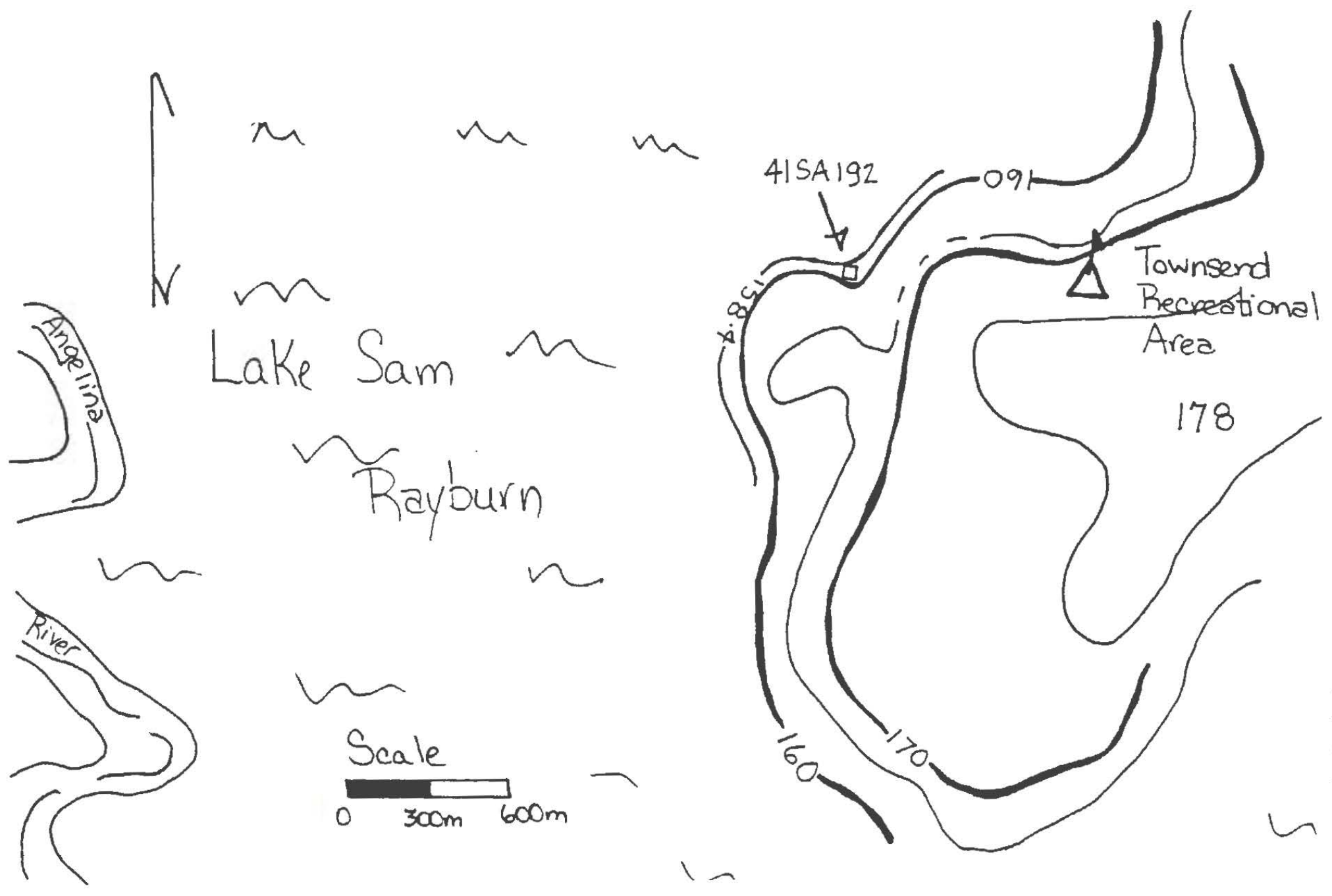

Figure 4. General Area of 41SA 192. 